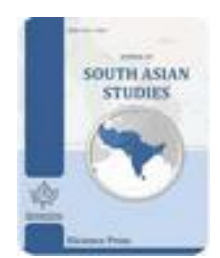

Available Online at EScience Press

Journal of South Asian Studies

ISSN: 2307-4000 (Online), 2308-7846 (Print)

https://esciencepress.net/journals/JSAS

\title{
ARBITRARY DETENTION: A CHALLENGE FACED BY MUSLIM MINORITY IN INDIA
}

\author{
Aijaz A. Turrey* \\ Centre for Studies in Economics and Planning, Central University of Gujarat, India.
}

*Corresponding Author Email ID: turreyaijaz@gmail.com

\begin{abstract}
A B S T R A C T
Muslims form the largest religious minority in India. Census of India 2011 registered about 14.4 per cent of India's total population as Muslims. Being minority Muslims are one of the weaker sections of society and the most oppressed ones. Majority of the Muslims especially youth are going through distress and trauma of terrorism tags. Muslims are the prime targets of anti-national activities and often jailed and killed in fake encounters. They are the most suffered section of the society and a little is being done for their upliftment. An attempt has been made to analyze the condition of the Muslim minority in India in the present democratic scenario. The study mainly focused on the consequences of false charges and fake encounters on the socio-economic conditions of Muslims and their families in India. The study is actually an investigation in some thrust areas in which Muslim section of the society is being demoralized deeply in India. The government of India established The Ministry of Minority Affairs on $29^{\text {th }}$ January 2006 to look after the issues of minority communities and suggest development frameworks for their benefit. The 2017 World Report of the Human Rights Watch ${ }^{1}$ also finds India as the violator of human rights with respect to freedom and treatment of minorities.

${ }^{1}$ An Indian government agency responsible for collecting and analyzing crime data as defined by the Indian Penal Code (IPC).
\end{abstract}

Keywords: Democracy, Muslim Minority, Arbitrary Detention, Terrorism, Fake Encounters.

\section{INTRODUCTION}

"Democracy is not a majority rule: democracy is diffusion of power, representation of interests, and recognition of minorities" (Roper, 1989). "Democracy is the form of state within which the distribution of power in the state is determined exclusively by the social factors of power but is not shifted in favour of any one class through the application of material means of coercion" (Meyer, 1957). India is a democratic country and an important feature of democracy is that it empowers people in a society to make decisions of their own. The liberal theory of democracy preaches that "in such a society, power rests with the citizen, who is entitled to certain freedoms (each of which has found its way into the universal declaration of human rights), including freedom of speech; freedom of information; freedom of worship and belief; freedom of the press; freedom of assembly; freedom to impart educational knowledge, and so on" (O'Byrne, 2005).

People choose a democratic government in order to remain in a state of protection, promotion and equality regarding their welfare, interests, freedom and rights. Freedom of participation in the community's formation of political self-government is required by democracy (C. F. Bahmueller, 2007).

India is considered a secular state having religious diversity and religious tolerance. According to the census data of 2011, there are more than six religious' groups in India. Out of the total population of $1,210,193,422$ people, Hindus account for 79.62 per cent, Muslims - 14.2 per cent, Christians - 2.34 per cent, Sikhs - 1.87 per cent, Buddhist - 0.77 per cent, Animist - 0.72 per cent, Jain 0.41 per cent and Parsis account for 0.06 per cent. In all the communities together, the number of youth in our country is 229 million forming about approximately 19 per cent of the population. Youth reflect the strength of a country particularly of a developing country like India. They are the pillars of development, war and labour (Gicharu, 2015). Youth is more sensitive. More the youth more will be the chances of insecurity leading to conflicts and hypertension situations. Youth protuberances are 
now a trendy explanation for the involvement of young people into terrorist and activist networks. Every year thousands of Muslim youth in India are arrested and the charges are theft, smuggling, terrorism, links to the underworld and the much more (Huntington, 1996).

The Preamble of the Constitution of India affirms the right to freedom and practicing of religion as a fundamental right. It also declares safety, security, fraternity and most important justice to each and everyone living in the country. Not only this, but it also aims at achieving such goals and reviewing the results of such objectives. It also focuses on the objectives of freedom of thought, expression, belief and unity and integrity of the nation. It also guarantees the equality of opportunity for all (Arora, 2010). Besides the national motto of the country is "Satyameva Jayate" which means "Truth Alone Triumphs". In this paper, attempt has been made to analyze the situation and status of Muslim youth in India. It will also be important to see whether the Preamble has been able to provide such rights and freedoms or not.

\section{RESEARCH QUESTIONS AND METHODOLOGY}

The study will focus on the following questions:

i. What is the socio-economic and political status of the Muslim Minority in India?

ii. What are the effects of false charges on Muslim Minority especially youth and their families?

The present study has been confined to the youth especially in Muslim Minority and weaker sections in India. It is based on both primary and secondary sources of data. The primary data regarding the study has been collected through interviews and group discussions method and data have also been obtained from National Crime Records Bureau (NCRB), An Indian government agency responsible for collecting and analyzing crime data as defined by the Indian Penal Code (IPC), Ministry of Home Affairs (MHA), relevant books, journals, articles and newspaper reports.

\section{SOCIO-ECONOMIC AND POLITICAL STATUS OF MUSLIMS IN INDIA}

On March 9, 2005, a High Level Committee was established on the orders of Prime Minister to prepare a report on the social, economic and educational status of the Muslim community of India. The report presented by the committee, the so-called "Sachar Committee" was really a depressing one. Although Muslims are India's biggest religious minority (Kirmani, 2016) they are the most suffered one. The year 2014 ended with 82190 Muslim prisoners in jails. Only 21550 were convicts while as 59550 were under trial cases. The number of detainees was 658. There is also a poor representation of Muslims in the police force (4-6 per cent) and government services (NCRB). When we look at the literacy rate among Muslims it was only $59.1 \%$ in 2001 which was much below even the national average of $64.8 \%$. It was also below the Hindu majority, SC and ST population. A simple argument that is being made by the authorities is that educational upliftment of the minorities is needed. It was also seen that the most educated unemployed are found among Muslims. The working population ratio for Muslims is considerably lower than for all other Socio Religious Categories (SRCs) in rural and urban areas. As a result, the earnings among them are very small. According to the Committee Report, "the most striking feature is the relatively high share of Muslim workers engaged in selfemployment activity," primarily in urban areas and for women workers. It was also observed that there is a complete absence of schools in many Muslim areas. They consume less and are below the basic standard level. Their bank credit savings are also low (Parker, 2006). The incidence of poverty is therefore likely to be higher among Muslims.

NSSO (National Sample Survey Organization) report also showed that out of the total poor population in 2004-05, $31 \%$ were Muslims. Many of the Muslim areas are without necessary medical facilities. The Muslim youth are often being used as subjects of false encounters and given the name of terrorists whenever there is political pressure upon the parties. The Muslims in overall are at the bottom. They are being discriminated in each and every sphere of life. Why only Muslims are considered antinationals? Have they any mark on their heads or face? Why a Muslim person with the beard is often suspected and arrested on the charges of terrorism or suspicion? Social boycott of Muslims in certain parts of the country has forced Muslims to migrate from the places where they lived for centuries, such as Gujarat during riots. The respective committees and organizations should intervene to provide fair social, political and economic justice to each and every resident of the country. The state and central governments should also intervene to nip the evil in the bud. But unfortunately, youth and particularly Muslim youth are the most widely affected portion in India. They are subjects of terror, threats, violence, charges and disappearance. They also suffered a lack of attention from the government (Alam, 2013). Farooq Ahmad Qasid and Nazir Ahmad Qasid are live examples, 
who were arrested for attacking the Red Fort in the year 2000 (Vallabha, 2005). They were detained in jails and released with honour after seven years by Delhi High Court even after getting close to a death sentence. Qateel Ahmad Siddiqui of Darbhanga got killed by armed forces inside the jail in Pune before any charges could be thrown at him (Swami, 2012). The police arrested a journalist, Muthi-ur-Rahman Siddiqui (Swami, 2012), Mohammed Yusuf Nalband and Aijaz Ahmed Mirza (The Hindu, 2013) on terror charges and released them after forty days.

There are thousands of other similar cases in the length and breadth of India. The Muslims are being demoralized socially, politically as well as economically (The Hindu, 2013). Who will return the eons they lived in Indian jails? They were not even provided any compensation. The remarkable fact is why some of the youth have encircled by the violence while others are totally ignorant of it. Everything that happens has a cause (C.F Bahmueller \& Argenti, 2002). The pieces of evidence from the National Crime Records Bureau showed that there is no end to the wild killings of innocent young Muslims. They are being victimized deliberately by the police particularly for the charges of being involved in human rights violations and terrorist acts. A different number of people is charged differently in different places. Sometimes youths are picked up and kept arrested for many days without informing the families. Muslims in many cases have been tortured badly in police and army custody. They were made to sign blank papers and confess crimes (Puniyani \& Hashmi, 2010). Both the police and people often humiliate Muslim youths on the basis of practicing religion. There is also a widespread police communalization across different parts of India. Thousands of youth disappearances have been observed so far but no strong enquiry has been made because of the involvement of security forces (Engineer, 2008). The State Department of USA has also cited that there is total negligence of the security forces towards the Indian Human Rights group. The abuses are in terms of torture of imprisoned, mass shooting of demonstrators, large scale illegal arrests, and killings in judicial custody, rape cases and confinement without trial (Bhatnagar, 2017). Muslim youth in India has been so blamed that their positive contribution in peacebuilding efforts has been almost rejected. It has also been found that most of the

1 The first anti-terrorism law legislated by the government to define and counter terrorist activities. youth are involved in peacebuilding efforts. However, there are also traces of involvement of Muslim youth in violent conflicts (Abdelhalim, 2016) but such a number is small when compared with non- Muslims in southern and north-eastern states.

\section{EFFECTS OF FALSE CHARGES ON MUSLIM YOUTH AND THEIR FAMILIES}

Many of the Muslim youth in India are still under imprisonment and suffer the humiliation of terrorist tag. The life of Muslims in India has become very difficult. Every breath they take is counted and watched. They are living a life of hardship. Fake encounters, false trials and charges, illegal arrests, detentions and lockups even in absence of pieces of evidence made their life miserable (Supreme Court of India, 2009). Illegal arrests not only harm those who are victims but also their families and relatives. In many areas, the conditions are as worse as were during the days of TADA ${ }^{1}$ (Terrorist and Disruptive Activities (Prevention) Act) and POTA2 (Prevention of Terrorism Act), 2002. A large number of Muslim youth is caught up in these cases every year. These false implications and charges allow the real perpetrators to go scot-free and do the same crimes again and again. It is clearly an injustice to both the parties. Innocent youths are locked up in jails for lengthy periods, denied passports, denied government jobs and lose respect. There are thousands of such cases were one finds innocent Muslim youths being killed, slapped false charges and thrown in Indian jails for years without any fair investigation (Alam, 2013).

Killing of Mohammed Afrazul on the name of love jihad in 2017 (Agarwal, 2017), torture and killing of Mohammad Sajid, a suspected Indian Mujahideen (IM) in Delhi bombings in 2008 (Tayler, 2011), long term imprisonment of Nisar-ud-din Ahmad (23 years) from Karnataka in 2016 (BBC, 2016), Muhammad Rafiq Shah from Srinagar in 2005 (Maqbool, 2017), acquitted and imprisoned in Delhi's Tihar Jail for 12 years over involvement in 2005 bomb blast case, Mohammad Aamir Khan (13+ years) in 1998 for masterminding 17 bomb blasts in Delhi (Vyawahare, 2013) and neighbouring states between December 1996 and December 1997 and killing of Ishrat Jahan in fake encounter are some of the cases revealing misery and desolation stories of innocent Muslims in India (Dasgupta, 2009). Also, there are

${ }^{2}$ Act passed by the Parliament of India in 2002, with the objective of strengthening anti-terrorism operations. 
hundreds of cases against armed forces for carrying out illegal activities like false encounters, rapes, threatening people, illegal arrests and much more. Nothing is being done to stop all this. Whenever a charge is slapped on any innocent his life becomes miserable. The worst situations in many places resulted in the forced movement of people from their home places where they lived for centuries. It severely affects their socio-economic life. Even the surrendered militants are being suspected and arrested again and again making their life acute and marginalized (Bloeria, 2001).

Many of the innocent people who have been released have not yet received their documents. Young educated youth who got opportunities for job and studying abroad are often disallowed because of terrorist tags of some relatives. They are consistently reporting that they are going through severe psychological, social and economic difficulties. Many educated and qualified students who should have been working as high officials are working on daily wage basis in lower private sectors. They should have high salaries but are having only subsistence wages. These problems can best be described by the victims only, who have tolerated them and not by those who are sitting on chairs in their offices and making repetitive arguments only. When an innocent is falsely charged and arrested, who cares what will happen to his family and children (Jaleel, 2016). How can a family survive who have their earners in the jails? Arresting youth and putting them in jails and releasing after years have become fun for the forces that are using their powers illegally. They do not care about people, what they care about is their post, position and promotion for which they are doing anything, legal as well as illegal. "There is nobody to monitor security agencies, which are free to do whatever they want. In many cases, innocent youths are being implicated in false terror charges" (Tripathi, 2013).

\section{CONCLUSION}

Muslims especially youth are used forefront of violent conflicts in India. They are often being used as subjects of all kinds of allegations and false charges. Muslim youth, particularly in India, have been given a tag "terrorist'. Terrorism is always linked with Muslims and/or Islam and is often being used as synonymous terms. Given tags are easy but bearing those tags is really too much difficult and the tag givers have never realized it. It is never examined whether there is really any evidence against them or not. The false cases destruct the lives of innocent picked-up youths. Muslims are the most suffered section of Indian society. They are often charged falsely stimulating them to stand against the law. India is considered a democratic nation but still much is needed to be called it democratic. Indian democracy is lame where there is an absence of equality of security, freedom, rights and opportunities. Such a serious issue should not be taken-up as lightly as it may provoke more and more conflicts and will add fuel to the fire.

\section{REFERENCES}

Abdelhalim, J. (2016). Indian Muslims and Citizenship Spaces for Jihad in Everyday Life. In. London: Routledge.

Agarwal, D. (2017). Questions That Have Been Troubling Me Since. In The Rajasthan Murder Video. India: Youth Ki Awaaz.

Alam, M. M. (2013). Quest for Equality, Equity and Justice: Requisites for Realisation. In. Commercial Street, London E1 6LT, UK: Minority Rights Watch.

Arora, P. (2010). Hope-in-the-Wall? A digital promise for free learning. British Journal of Educational Technology, 41(5), 689-702. doi:10.1111/j.14678535.2010.01078.x

Bahmueller, C. F. (2007). The Fundamental Principles, Concepts, Social Foundations, and Processes of Democracy. In Elements of Democracy. California: Center for Civic Education.

Bahmueller, C. F., \& Argenti, P. A. (2002). How Women Contain Violence in Southern Sri Lanka. In Masking Terror. Philadelphia: University of Pennsylvania Press.

BBC. (2016). India man struggles with freedom 23 years after 'wrong' conviction. In: BBC News.

Bhatnagar, G. V. (2017). US State Department Report Highlights India's Human Rights Violations, Actions against Civil Society Groups. In. USA: The Wire.

Bloeria, S. S. (2001). Militancy in Rajouri and Poonch. Special Commissioner, Rajouri \& Poonch (1990 and 1992), Principal Secretary, Health \& Medical Education, Government of J\&K.

Dasgupta, M. (2009). Ishrat Jahan killing also a fake encounter: probe report. In. Chennai, India: The Hindu.

Engineer, A. A. (2008). Terrorism, communal violence and police, Two Circles. In. USA: Mainstream News of the Marginalized.

Gicharu, S. (2015). The Youth are the Pillars of Development. In. Kenya: Daily Nation. 
Huntington, S. P. (1996). The Clash of Civilizations and the Remaking of the World Order. In. New York, USA: The New York Times.

Jaleel, M. (2016). After 23 years in Jail, I am Free but what you see now is a Living Corpse. In. India: The Indian Express.

Kirmani, N. (2016). How Oppressed are Muslims in India? In. Karachi, Pakistan: Herald.

Maqbool, M. (2017). Acquitted After 12 Years in Jail, Kashmiri Student Wants To Go Back To His Books. In. India: The Wire.

Meyer, A. G. (1957). Leninism. In. Cambridge, UK: Harvard University Press.

0’Byrne, D. J. (2005). Human Rights: An Introduction. In. New Delhi, India: Pearson Education Ltd.

Parker, J. (2006). In Good Faith: Schools, Religion, and Public Funding. In: Taylor \& Francis Online Survey. Puniyani, R., \& Hashmi, S. (2010). Mumbai: Post 26/11: An Alternate Perspective. In. India: SAGE Publications.

Roper, J. (1989). Democracy and Its Critics: AngloAmerican Democratic Thought in the Nineteenth
Century. In. Winchester, England: Routledge Revivals.

Supreme Court of India. (2009). Criminal Appeal Nos. 523-527 of 2009.

Swami, P. (2012). Prison murder could hold clues to Pune attack. In. Chennai, India: The Hindu.

Tayler, L. (2011). The "Anti-Nationals" Arbitrary Detention and Torture of Terrorism Suspects in India. In The Anti-Nationals. New York, NY 101183299 USA: Human Rights Watch.

The Hindu. (2013). It's tough for us to even book a train ticket. In. Chennai, India: The Hindu.

Tripathi, A. (2013). Prakash Karat Demands Release of Innocent Muslims Implicated in False Terror Charges. In. India: The Times of India.

Vallabha, S. R. (2005). Court convicts 7 for Red Fort attack. In. India: Rediff, India Abroad.

Vyawahare, M. (2013). Mohammad Aamir Khan's 14 Lost Years. In. 620 Eighth Avenue, New York: The New York Times.

Publisher's note: EScience Press remains neutral with regard to jurisdictional claims in published maps and institutional affiliations.

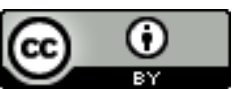

Open Access This article is licensed under a Creative Commons Attribution 4.0 International License, which permits use, sharing, adaptation, distribution and reproduction in any medium or format, as long as you give appropriate credit to the original author(s) and the source, provide a link to the Creative Commons license and indicate if changes were made. The images or other thirdparty material in this article are included in the article's Creative Commons license, unless indicated otherwise in a credit line to the material. If material is not included in the article's Creative Commons license and your intended use is not permitted by statutory regulation or exceeds the permitted use, you will need to obtain permission directly from the copyright holder. To view a copy of this license, visit http://creativecommons.org/licenses/by/4.0/.

(c) The Author(s) 2019. 